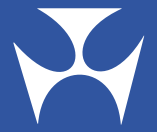

Reserve Bank of Australia

\section{RESEARCH \\ DISCUSSION \\ PAPER}

\section{Understanding the Flattening Phillips Curve}

Ken Kuttner and

Tim Robinson

RDP 2008-05 


\title{
UNDERSTANDING THE FLATTENING PHILLIPS CURVE
}

\author{
Ken Kuttner and Tim Robinson \\ Research Discussion Paper \\ 2008-05
}

October 2008

Economic Research Department

Reserve Bank of Australia

This research was initiated while Ken Kuttner was a visiting scholar at the RBA. Allen Tran provided exceptional research assistance. We have received useful comments from Jeremy Rudd and Charles Steindel. The views expressed herein are those of the authors and not necessarily the Reserve Bank of Australia. Any errors are our own.

Authors: kenneth.n.kuttner at domain williams.edu or robinsont at domain rba.gov.au

Economic Publications: ecpubs@rba.gov.au 


\begin{abstract}
Policy-makers have recently noted an apparent flattening of the Phillips curve. The implications of such a change include that a positive output gap would be less inflationary, but the cost of reducing inflation, once established, would increase. This paper's objective is to review the evidence and possible explanations for the flattening of the Phillips curve in the context of new-Keynesian economic theory. Using data for the United States and Australia, we find that the flattening is evident in the baseline 'structural' new-Keynesian Phillips curve. We consider a variety of reasons for this structural flattening, such as data problems, globalisation and alternative definitions of marginal cost, none of which is entirely satisfactory.
\end{abstract}

JEL Classification Numbers: E31, E32

Keywords: Phillips curve, inflation 


\section{Table of Contents}

$\begin{array}{ll}\text { 1. Introduction } & 1\end{array}$

2. Reduced-form Flattening 2

3. A Structural Perspective on the Flattening Issue 5

3.1 A Brief Review of New-Keynesian Inflation Theory 5

4. Has the New-Keynesian Phillips Curve become Flatter? 8

4.1 Baseline New-Keynesian Phillips Curve Estimates 9

5. Explaining the Flattening Phenomenon 15

5.1 Data Problems 16

5.2 Labour Share $\neq$ Marginal Cost 17

5.2.1 Open economy dimensions $\quad 17$

5.2.2 Changing sectoral composition 20

5.3 Structural Changes in Price-setting Behaviour 20

5.3.1 The Rogoff hypothesis 20

5.3.2 Increased openness of product and labour markets 21

5.4 The Need for a Richer Structural Model 22

6. Conclusions 23

$\begin{array}{ll}\text { References } & 24\end{array}$ 


\title{
UNDERSTANDING THE FLATTENING PHILLIPS CURVE
}

\author{
Ken Kuttner and Tim Robinson
}

\section{Introduction}

In recent years, inflation appears to have become less responsive to fluctuations in output and unemployment - that is, the Phillips curve has become 'flatter'. This has been documented for the United States by Roberts (2006), among others, and a similar phenomenon seems to have occurred in other countries as well (for example, see Beaudry and Doyle 2000 for Canada).

A decline in the output-inflation trade-off, if it has occurred, would have consequences for monetary policy. As discussed in Bean (2006) and Mishkin (2007b), a benefit is that higher levels of the output gap and lower levels of unemployment would be less inflationary. The problem is that inflation, once established, would be harder to bring down.

While the stylised fact of a flatter Phillips curve has been reasonably well established, the precise reasons for this change are not well understood. Firmer anchoring of inflation expectations is one possibility, advanced by Roberts (2006), Williams (2006) and Mishkin (2007b), among others. (This line of reasoning has tended to emphasise the effects of anchoring on inflation persistence rather than the responsiveness of inflation to fluctuations in real activity.) Others, such as Borio and Filardo (2007) and Razin and Binyamini (2007), cite the effects of globalisation.

The purpose of this paper is, therefore, to understand why the Phillips curve seems to have become flatter, using insights from new-Keynesian macroeconomic theory to dissect the linkages between real activity and inflation. Variants of the newKeynesian framework are extensively used in macroeconomic models at central banks worldwide (for example, at the Riksbank - Adolfson et al 2007, and the Bank of Canada - Murchison and Rennison 2007). According to this perspective, a fruitful way to think about the reduced-form output-inflation nexus is in two stages: first, as a relationship between the output gap and costs; and second, in terms of the linkage between costs (or more precisely, the current and expected 
future costs) and inflation. A reduction in the overall sensitivity of inflation to output may result from a change in either one of those two stages.

The paper proceeds as follows. Section 2 (briefly) documents the change in the reduced-form Phillips curve in the United States and a small open economy, namely Australia. Section 3 reviews the new-Keynesian inflation model and discusses why a change in the reduced form need not imply a change in firms' price-setting behaviour. In an effort to determine whether there may also have been a change in the structural inflation equation, in Section 4 we estimate the newKeynesian Phillips curve, finding that there does appear to have been a reduction in the responsiveness of inflation to marginal costs. Section 5 considers several possible explanations for these findings, none of which is entirely satisfactory.

\section{Reduced-form Flattening}

Simple scatterplots of inflation and the output gap are striking (Figure 1). We divide the sample for both countries, with the period after the break displaying a sizeable drop in the volatility of the output gap in each country. ${ }^{1}$ The moderation of the business cycle has been widely studied - see, for example, the papers in Kent and Norman (2005). The accompanying decline in inflation, however, has not been proportional - the reduced-form Phillips curve has flattened.

Reduced-form estimates of the Phillips curve, like those in Roberts (2006), typically have the specification:

$$
\pi_{t}=a+b(L) \pi_{t-1}+c y_{t-1}+d z_{t}+e_{t}
$$

where: $\pi_{t}$ is quarterly inflation; $y_{t}$ is an estimate of the output gap; $L$ is the lag operator; and $z_{t}$ represents some exogenous factors affecting inflation. ${ }^{2}$ The lags of inflation (we use two) are sometimes interpreted as a proxy for inflation

1 The break in 1984:Q1 for the United States follows Roberts (2006). The break in 1993:Q1 for Australia corresponds to the adoption of inflation targeting. The output gap is constructed using a quadratic trend - see Section 4 for further details on the data.

2 In the rolling regressions we exclude $z_{t}$. Including the change in import prices moderates the extent of the flattening evident for the United States, but not for Australia. Adding further lags of inflation or changes in oil prices does not change our results qualitatively. 


\section{Figure 1: Inflation and the Output Gap}

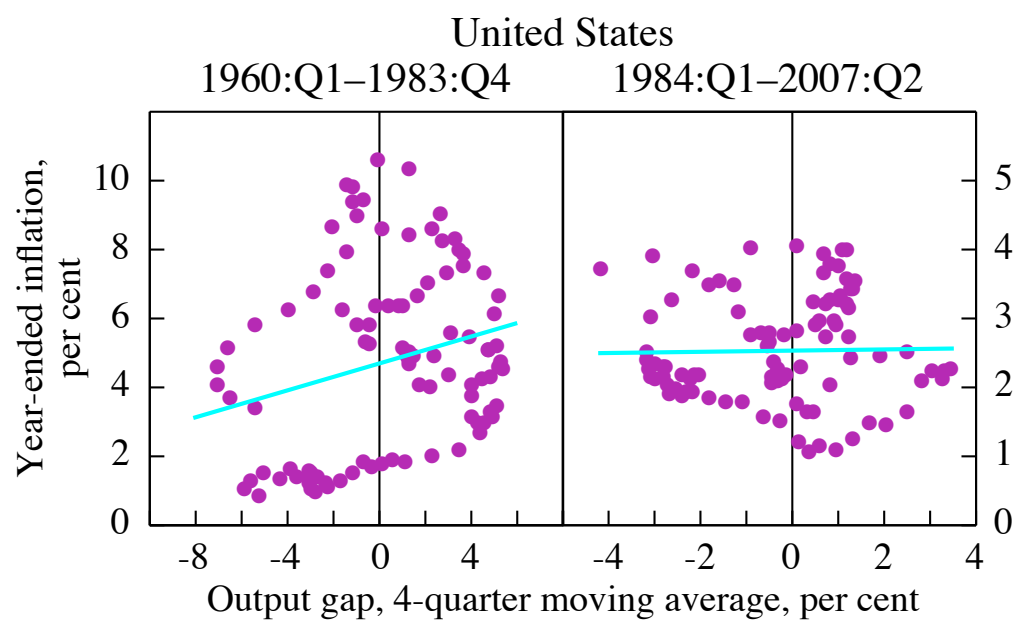

Australia

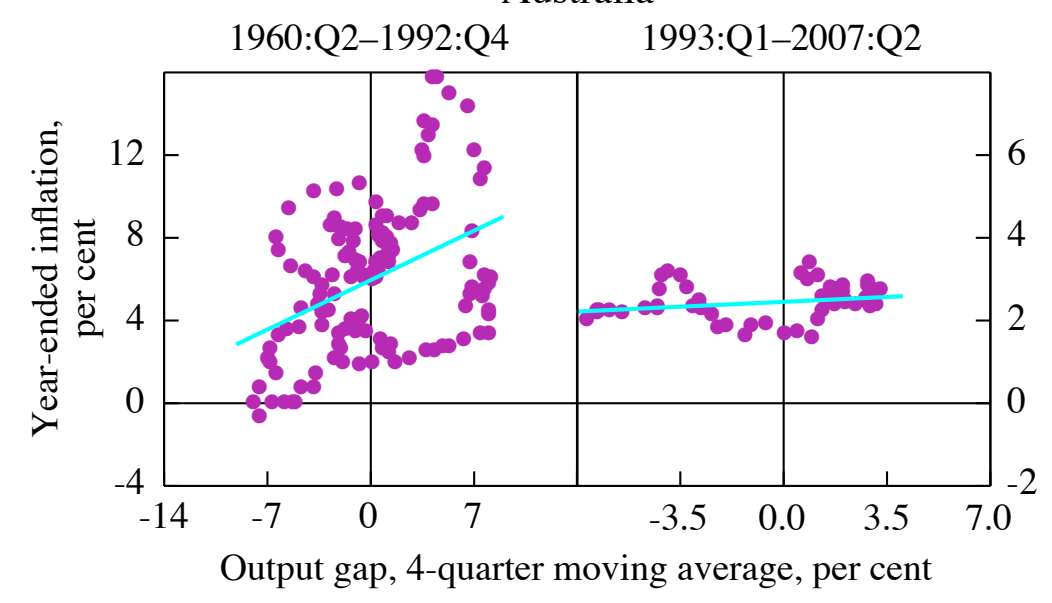

expectations, and more generally to capture the observed persistence in inflation. ${ }^{3}$ To examine the flattening of the Phillips curve we want to allow $c$, the coefficient on the output gap, to vary over time. Two simple ways of doing this are to estimate Equation (1) over a 15-year rolling window (Figure 2), or to specify the process so that the output gap coefficient follows (we assume a random walk) and to use the Kalman filter to estimate it over time (Figure 3). The latter has the advantage that

3 Often the coefficients on the lags of inflation are restricted to sum to 1 (and the constant restricted to be 0), in an attempt to ensure that the Phillips curve is vertical in the long run (this is the 'accelerationist' model of inflation). These restrictions imply that inflation is an integrated process, which is implausible when the central bank's reaction function satisfies the 'Taylor Principle', that is, they move the nominal interest rate more than one-for-one in response to expected inflation. They also ignore the cross-equation restrictions that would exist in a fully-specified model - a point first highlighted by Sargent (1971). However, whether the Federal Reserve tightened sufficiently to offset inflation in the 1970s is debatable - see Clarida, Galí and Gertler (2000) and Orphanides (2002). 
it delivers two-sided estimates, that is, at all points of time they use information from the entire sample.

\section{Figure 2: Output Gap Coefficient}

15-year rolling regressions

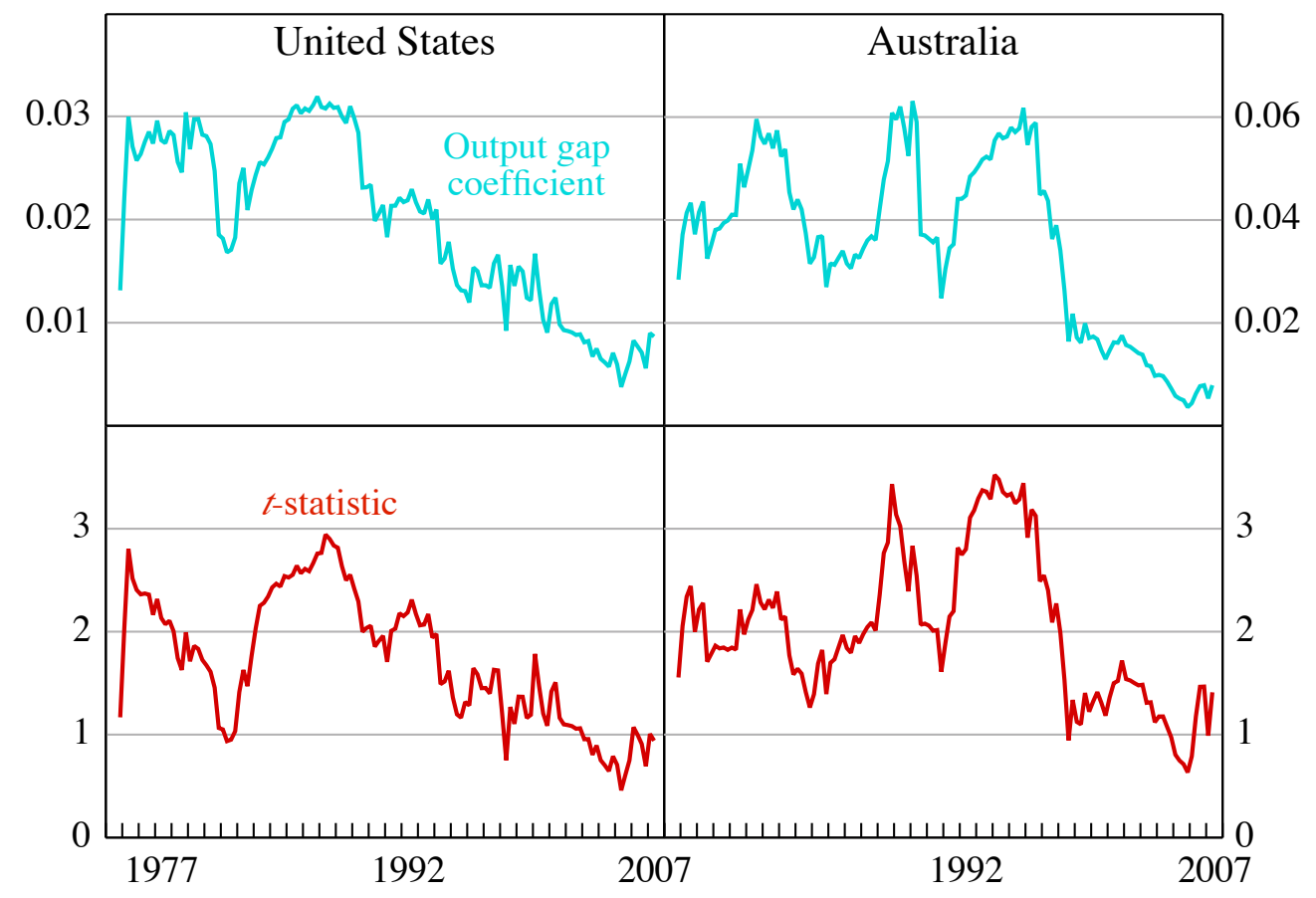

Note: The null hypothesis is that the coefficient on the output gap is zero.

The flattening of the reduced-form Phillips curve is clearly evident for the United States using either methodology. In Figure 2 we date the parameter estimates at the end of each rolling window, and consequently the sharp reduction in the output gap's coefficient evident from around 1989 occurred in the preceding 15 years, and perhaps is better dated in the early 1980s, around the time when the Federal Reserve managed to reduce inflation. Alternatively, the two-sided estimates in Figure 3 suggest that the flattening of the Phillips curve began around 1975 and has been a very gradual process which continued over the 1980s and 1990s. ${ }^{4}$

The results for Australia are more mixed. The estimates of the coefficient on the output gap fluctuate considerably until the late 1990s, after which there is a clearly discernable downward trend. Once again, this suggests that the flattening began around the time of a change in monetary policy regime, namely the adoption

4 Naturally, this partially reflects our assumption that the coefficient on the output gap follows a random walk. The start date for the time-varying parameter estimates is 1970:Q1. 
of inflation targeting. The two-sided estimates, however, date the flattening as beginning far earlier, around 1975, akin to the findings for the United States.

\section{Figure 3: Time-varying Estimates of the Output Gap Coefficient}

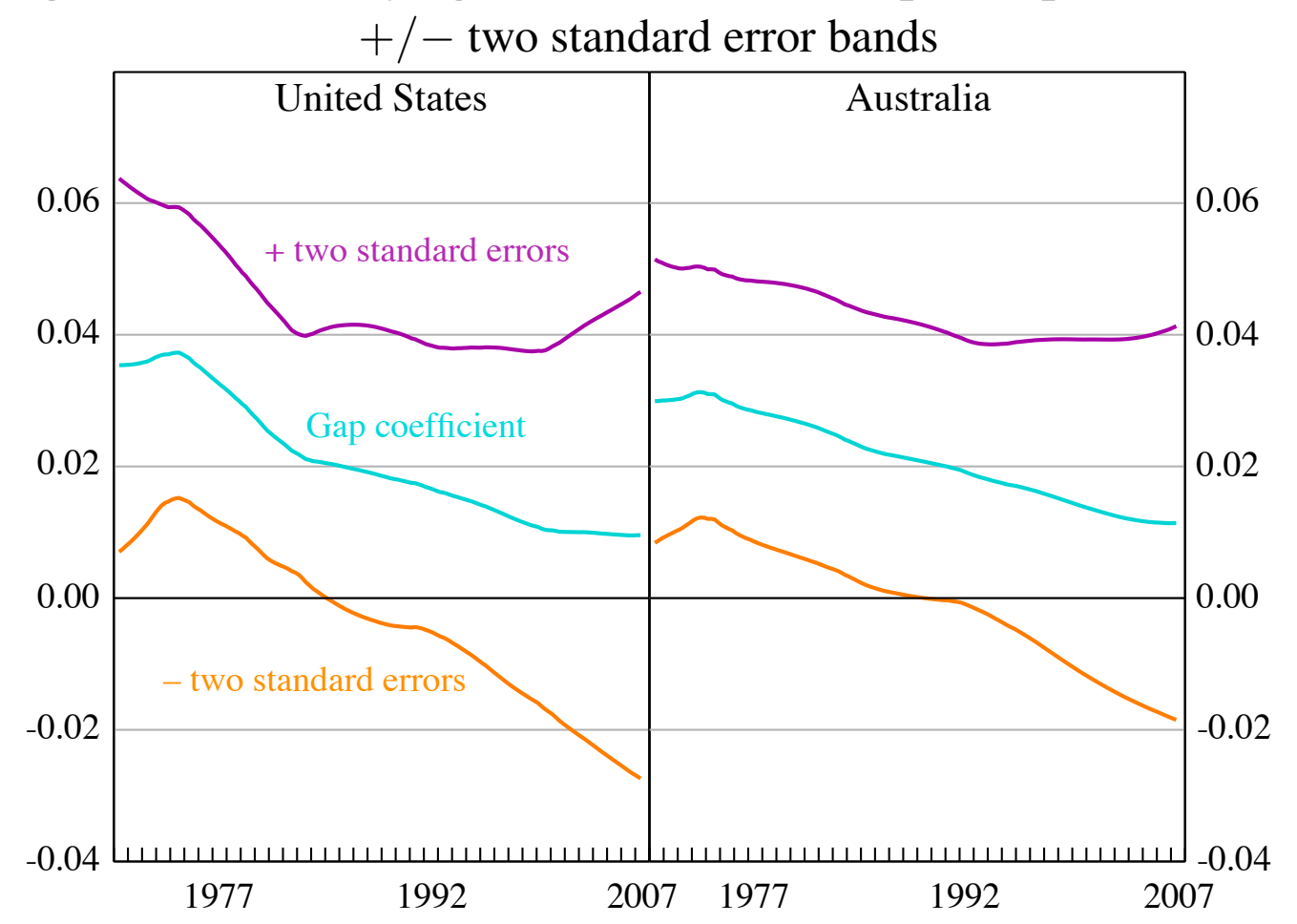

\section{A Structural Perspective on the Flattening Issue}

The problem with the results above is that, because they come from reducedform regressions, it is hard to tell whether they represent a change in the true responsiveness of inflation to the output gap, as opposed to a change elsewhere in the economy (for example, in the policy rule, if the central bank decided to respond more aggressively to expected inflation). This is just the Lucas critique (Lucas 1976). Consequently, we now turn to more structural estimates of the inflation process. We adopt the common new-Keynesian framework to examine whether a flattening has occurred and, if so, to review its possible causes.

\subsection{A Brief Review of New-Keynesian Inflation Theory}

The basic idea of the new-Keynesian Phillips curve is that, in an environment in which there are only occasional opportunities to adjust prices, firms will set their prices in anticipation of expected future costs. The key points are that prices are determined by costs (via a desired price/cost mark-up), and that there is a 
forward-looking element to price setting. For an extensive survey of the literature see Òlafsson (2006).

The canonical expression of this theory is the new-Keynesian Phillips curve,

$$
\pi_{t}=\beta E_{t} \pi_{t+1}+\lambda m c_{t},
$$

as derived in Galí and Gertler (1999), where $\beta$ is the discount factor, $m c$ is the real marginal cost and $\lambda$ is its coefficient. However, this specification has been found to not capture the observed persistence of inflation. Consequently, it has been generalised by introducing either rule-of-thumb pricing (Galí and Gertler), or indexation (Christiano, Eichenbaum and Evans 2005), both of which have the result of introducing a lag of inflation to the Phillips curve:

$$
\pi_{t}=\gamma_{f} E_{t} \pi_{t+1}+\gamma_{b} \pi_{t-1}+\lambda m c_{t} .
$$

This is commonly referred to as the hybrid new-Keynesian Phillips curve, and the $\gamma_{f}$ and $\gamma_{b}$ coefficients respectively reflect the degree of 'forward lookingness' and inertia in inflation. ${ }^{5}$

What makes Equation (3) attractive is that it can be derived from explicit microeconomic foundations, such as Calvo pricing (Calvo 1983), as sketched in Galí and Gertler (1999). ${ }^{6}$ Specifically, let $\theta$ represent the probability that a firm is unable to adjust its prices in any given period. Furthermore, let $\omega$ represent the share of firms who can change their price, but instead of doing so optimally follow a 'rule of thumb' and base their price adjustment on lagged inflation, while the remaining $1-\omega$ set their prices optimally. ${ }^{7}$ In this case, the $\gamma_{f}, \gamma_{b}$ and $\lambda$ parameters are functions of the deep parameters $\omega$ and $\theta$, and the discount factor $\beta$ as follows:

5 Nimark (2008) provides an alternative explanation for the inertia, namely imperfect information about firms' marginal costs.

6 An alternative approach is to use quadratic adjustment costs; see Rotemberg (1982).

7 In the steady state there is assumed to be no inflation, although this is relaxed by Ascari (2004), who argues that the assumption is not innocuous. We revisit this in Section 5.4. 


$$
\begin{aligned}
\lambda & =(1-\omega)(1-\theta)(1-\beta \theta) \phi^{-1} \\
\gamma_{f} & =\beta \theta \phi^{-1} \\
\gamma_{b} & =\omega \phi^{-1}, \text { where } \\
\phi & =\theta+\omega[1-\theta(1-\beta)] .
\end{aligned}
$$

It is possible to solve the new-Keynesian Phillips curve forward, for example, using the approach of Binder and Pesaran (1995), which yields:

$$
\pi_{t}=P \pi_{t-1}+\frac{\lambda}{1-\gamma_{f} P} \sum_{i=0}^{\infty}\left(\frac{\gamma_{f}}{1-\gamma_{f} P}\right)^{i} E_{t} m c_{t+i}
$$

where $P=\frac{1 \pm \sqrt{1-4 \gamma_{f} \gamma_{b}}}{2 \gamma_{f}}$, and $|P|<1 .^{8}$

This highlights that, in this framework (abstracting from the lagged inflation term), it is the expected path of current and future real marginal costs that determines current inflation.

Finally, the closed form can be used to see why the reduced-form estimates may not actually correspond to a structural flattening of the Phillips curve. Suppose, just as an illustration, that real marginal costs follows an AR(1) process,

$$
m c_{t}=\rho m c_{t-1}+u_{t}
$$

so that

$$
\sum_{i=0}^{\infty}\left(\frac{\gamma_{f}}{1-\gamma_{f} P}\right)^{i} E_{t} m c_{t+i}=\sum_{i=0}^{\infty}\left(\frac{\gamma_{f} \rho}{1-\gamma_{f} P}\right)^{i} m c_{t}=\frac{m c_{t}}{1-\frac{\gamma_{f} \rho}{1-\gamma_{f} P}} .
$$

Under this assumption, the closed form of the new-Keynesian Phillips curve can be written very simply as

$$
\pi_{t}=P \pi_{t-1}+\frac{\lambda}{1-\gamma_{f}(P+\rho)} m c_{t} .
$$

What is interesting is that, except for the substitution of the real marginal cost $m c$ for the conventional output gap, this is indistinguishable from the reduced-form

8 Note that this does not guarantee a unique solution. For stability we also need $\left|\frac{\gamma_{f}}{1-\gamma_{f} P}\right|<1$. 
Phillips curves that are often estimated. As usual, the reduced-form coefficients are complicated functions of the underlying parameters of interest. A flattening of the reduced-form Phillips curve can reflect, in this example, either a change in the slope of the structural Phillips curve (a reduction in $\lambda$ ) or a decrease in the persistence of marginal cost fluctuations. Thus, the reduced-form Phillips curve may flatten for reasons completely unrelated to any structural change in the relationship between prices and marginal costs.

This is not a new idea. Roberts (2006) examines the implications for estimates of the slope of the reduced-form Phillips curve of changes in the monetary policy rule, and finds that more responsive policy could underlie a reduced-form flattening. Similar results were obtained analytically by Carlstrom, Fuerst and Paustian (2007). ${ }^{9}$

Changes in the link between the output gap and marginal costs are another possible source of change in the relationship between inflation and the output gap. Specifically, if marginal costs become less sensitive to fluctuations in economic activity, then inflation will be less sensitive to the output gap.

\section{Has the New-Keynesian Phillips Curve become Flatter?}

In principle, a correctly-specified new-Keynesian Phillips curve model should not be affected by changes elsewhere in the economy, such as in the policy rule, as it is structural. ${ }^{10}$ Also, as these Phillips curves typically rely on direct measures of marginal costs, they should not be affected by any changes in the sensitivity of marginal costs to real activity. Determining whether the estimated new-Keynesian Phillips curve has changed is therefore essential to understanding the likely sources of the instability evident in the reduced-form relationship.

To preview: the results reported in this section suggest that the flattening phenomenon is not limited to reduced-form output-inflation models. Rather, there also seems to have been a change in the linkage between marginal costs (or at least their commonly-used proxy) and inflation. Possible reasons for this breakdown will be explored later, in Section 5.

\footnotetext{
9 Interestingly, Rudebusch (2005) found quantitatively small effects of increasing 'aggressiveness' on the reduced-form parameter estimates.

10 We revisit this in Section 5.4.
} 


\subsection{Baseline New-Keynesian Phillips Curve Estimates}

We estimate the new-Keynesian Phillips curve for the United States using Generalized Method of Moments (GMM) to handle the expectations term, and closely follow Galí, Gertler and Lopez-Salido (2005) and Galí and Gertler (1999). ${ }^{11}$ Briefly, assuming that expectations are rational, they will be based on all of the available information, and therefore expectations errors should, on average, be unrelated to the available information (the instruments). ${ }^{12,13}$ In practice, there are several issues with GMM estimation, such as the choice of an appropriate instrument set and lag length to be used in the calculation of robust standard errors and the weighting matrix. Also, when we estimate the deep parameters (for example $\omega$, the share of rule-of-thumb price setters) the model is non-linear, and in this instance the GMM estimates are sensitive to the normalisation used. Many of these issues and their implications for the new-Keynesian Phillips curve are discussed in detail by Guay and Pelgrin (2004), who found that the GMM parameter estimates can be quite sensitive to these modeling choices.

The data we use for the US follow Galí and Gertler (1999). We model the GDP chain price index. The other series (except for the output gap) are for the nonfarm business sector. As is standard practice in the literature, real marginal costs are measured using labour's share of income (an assumption which is discussed further in Section 5.2). We use average hourly compensation as a measure of wages, and estimate the output gap using a quadratic trend.

11 Estimates for Australia, which include open economy aspects, are presented in Section 5.2.1.

12 Galí, Gertler and Lopez-Salido (2001) also instrument real marginal costs, in part, as it may be measured with error, and we do so as well. We also discuss possible data problems in Section 5.1.

13 The instruments we use include: a constant, lags 1-4 of inflation, lags 1-2 of the output gap, real marginal costs and nominal wages (following Galí et al 2001). 
Table 1 presents two sets of estimates of the 'reduced-form' hybrid new-Keynesian Phillips curve (Equation (3)) for the United States. Galí and Gertler (1999) refer to this as the reduced form as it does not estimate the deep parameters. The first set of results attempts to replicate the results in Galí et al (2005); it is estimated over the sample 1960:Q1-1997:Q4 and uses real-time data from the St. Louis ALFRED database and their instrument set. ${ }^{14}$ These results are indeed very similar, although the standard error for $\lambda$, the coefficient on marginal cost, is slightly larger. The second set of results estimates exactly the same regression but using a recent vintage (2007:Q3) of data. Focusing on the estimates of the slope of the Phillips curve, $\lambda$, what is stark is that it has reduced by around one-quarter entirely due to data revisions, and its significance has decreased. ${ }^{15}$ The estimates over the full sample, (1960:Q1-2007:Q2), however, suggest that the decrease in $\lambda$ is not entirely due

\begin{tabular}{|c|c|c|c|c|c|c|}
\hline \multicolumn{7}{|c|}{$\begin{array}{l}\text { Table 1: New-Keynesian Phillips Curve - United States } \\
\qquad \pi_{t}=\gamma_{f} E_{t} \pi_{t+1}+\gamma_{b} \pi_{t-1}+\lambda m c_{t}\end{array}$} \\
\hline \multirow[t]{4}{*}{$\overline{\text { Coefficient }}$} & \multirow{2}{*}{\multicolumn{4}{|c|}{$\begin{array}{c}\text { 1960:Q1-1997:Q4 } \\
\text { Galí et al (2005) sample }\end{array}$}} & \multirow{3}{*}{\multicolumn{2}{|c|}{$\begin{array}{c}\text { 1960:Q1-2007:Q2 } \\
\text { Full sample } \\
\text { 2007:Q3 vintage data }\end{array}$}} \\
\hline & & & & & & \\
\hline & \multicolumn{2}{|c|}{ Real-time data } & \multicolumn{2}{|c|}{ 2007:Q3 vintage data } & & \\
\hline & Value & $\begin{array}{l}\text { Standard } \\
\text { error }\end{array}$ & Value & $\begin{array}{c}\text { Standard } \\
\text { error }\end{array}$ & Value & $\begin{array}{c}\text { Standard } \\
\text { error }\end{array}$ \\
\hline$\overline{\gamma_{b}}$ & 0.363 & 0.062 & 0.325 & 0.089 & 0.305 & 0.089 \\
\hline$\gamma_{f}$ & 0.630 & 0.058 & 0.661 & 0.084 & 0.689 & 0.087 \\
\hline \multirow[t]{2}{*}{$\lambda$} & 0.012 & 0.008 & 0.009 & 0.007 & 0.007 & 0.005 \\
\hline & \multicolumn{6}{|c|}{ Imposing $\gamma_{f}+\gamma_{b}=1$} \\
\hline$\gamma_{b}$ & 0.361 & 0.064 & 0.320 & 0.091 & 0.302 & 0.090 \\
\hline$\lambda$ & 0.011 & 0.006 & 0.007 & 0.006 & 0.006 & 0.004 \\
\hline
\end{tabular}

Notes: Estimated using 2SLS with Newey-West standard errors (using 12 lags). Instruments: constant, $\pi_{t-1}$ to $\pi_{t-4}$, lags 1-2 of the output gap, real marginal costs and nominal wages (following Galí et al 2001).

14 The data are as close to that used by Galí et al (2005) as was possible, but are not identical. The price index is the 1998:Q2 vintage; for the non-farm business sector the first vintage available was 1999:Q3.

15 The importance of the data vintage has also been noted by Rudd and Whelan (2005) and Guay and Pelgrin (2004). In the context of a conventional, reduced-form specification, Koenig (2003) also found that the significance of unit labour costs was sensitive to data vintage. 
to data revisions. ${ }^{16}$ Similar results are obtained if we constrain the coefficients on inflation expectations and lagged inflation to sum to 1 (which implies that $\beta=1$ ). Pagan (2008) shows that this constraint allows the first lag of inflation to be an instrument for variables other than itself (rather than using deeper lags), which may lessen problems with weak instruments.

Repeating the rolling regression exercise, but this time for the new-Keynesian Phillips curve, also suggests that a flattening has occurred (Figure 4). ${ }^{17}$ Interestingly, compared to the reduced-form estimates, it dates the flattening as having occurred much later, possibly from the early 1990s onwards.

Figure 4: Slope of the New-Keynesian Phillips Curve United States, 15-year rolling regressions

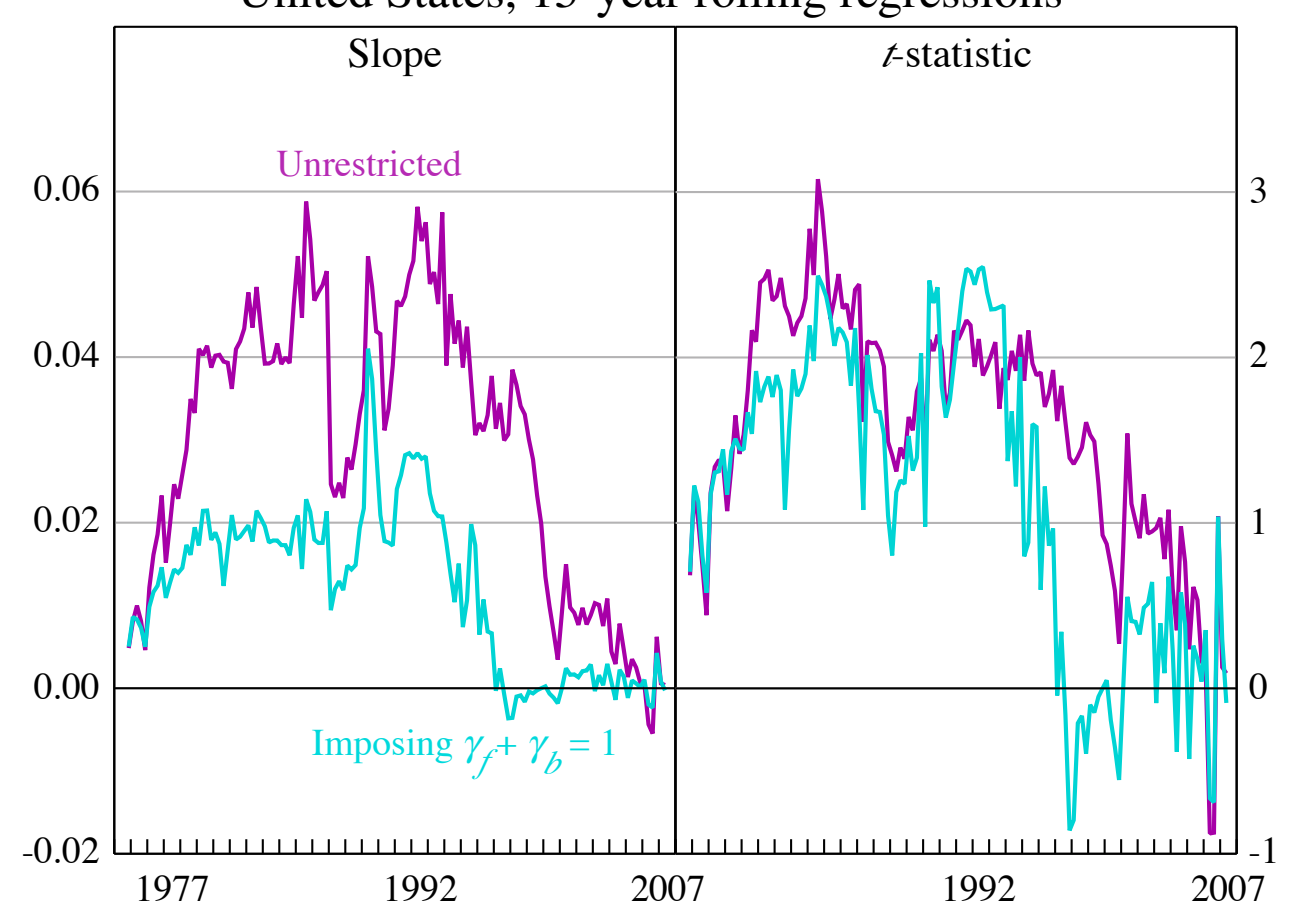

Note: $\quad t$-statistic is for the null hypothesis that the slope of the Phillips curve is zero.

In all, it appears that the flattening of the Phillips curve for the United States may not only be a reduced-form phenomenon.

\footnotetext{
16 Estimates using the 2007:Q3 vintage of the labour share for the whole economy, rather than the non-farm business sector, display a similar decrease in $\lambda$.

17 An obvious caveat to these results is that GMM is a large sample estimator.
} 
One approach to try to understand what might have caused this flattening is to look at estimates of the deeper 'structural' parameters. Table 2 estimates these over the the entire sample (1960:Q1-2007:Q2) and the sub-samples used in the initial scatterplots of Section 2, namely 1960:Q1-1983:Q4 and 1984:Q1-2007:Q2. Two findings emerge, and these are uniform in direction across the different normalisations and whether or not $\beta$ is restricted to be $1 .{ }^{18}$ First, the Calvo parameter, namely the probability that a firm will be unable to change its price in any given period, appears to have increased, which implies that the average duration between price changes has lengthened considerably. This result adds to the well-known tension between macro-based estimates, such as these, and the much shorter duration between price changes evident from micro data (see Bils and Klenow 2004). Indeed, some of the estimates of the duration between price changes (particularly those from the second moment condition) seem implausibly long. Second, the share of rule-of-thumb firms appears to have decreased. The first finding is consistent with a flattening of the Phillips curve, whereas the second would make it steeper. Overall, it appears the impact of the increase in the Calvo parameter dominates.

Another way of trying to gain an intuitive understanding of why this is the case is to look at the data.

Figure 5 suggests the source of this change: in the United States, at least, there has been a sharp downward trend in labour's share of income since the beginning of the 1990s (the date of the flattening identified by the rolling regressions) or a little earlier, although it is punctuated by a sharp (temporary) upward surge late in the decade. ${ }^{19} \mathrm{Had}$ inflation responded in the usual way (that is, with the 'old' estimate of $\lambda$ ), this would have resulted in a significant trend decline in the inflation rate; instead, inflation fell only modestly over this period (and crept up only slightly in the late 1990s). This is illustrated in Figure 6, which plots a dynamic inflation forecast from the new-Keynesian Phillips curve, conditional on the observed path of marginal costs. ${ }^{20}$

\footnotetext{
18 They also remain if the sample is split later, for example, in the early 1990s.

19 Interestingly, as noted by Lawless and Whelan (2007), a comparable downward trend in labour's share is also observed in euro area countries, with a similarly small drop in inflation.

20 This is the 'fundamental inflation' plotted in Galí and Gertler (1999) and Galí et al (2001).
} 
Table 2: Structural Estimates of the New-Keynesian Phillips Curve - US

\begin{tabular}{|c|c|c|c|c|}
\hline \multirow[t]{2}{*}{ Coefficient } & \multicolumn{2}{|c|}{ Moment condition $1^{(a)}$} & \multicolumn{2}{|c|}{ Moment condition $2^{(b)}$} \\
\hline & Value & Standard error & Value & Standard error \\
\hline \multicolumn{5}{|c|}{ 1960:Q1-1983:Q4 } \\
\hline$\theta$ & 0.829 & 0.037 & 0.837 & 0.044 \\
\hline$\omega$ & 0.214 & 0.158 & 0.395 & 0.160 \\
\hline$\beta$ & 0.999 & 0.051 & 0.994 & 0.056 \\
\hline Implied $\lambda$ & 0.022 & & 0.013 & \\
\hline \multicolumn{5}{|c|}{ Imposing $\beta=1$} \\
\hline$\theta$ & 0.828 & 0.037 & 0.837 & 0.044 \\
\hline$\omega$ & 0.213 & 0.162 & 0.394 & 0.162 \\
\hline Implied $\lambda$ & 0.022 & & 0.013 & \\
\hline \multicolumn{5}{|c|}{ 1984:Q1-2007:Q2 } \\
\hline$\theta$ & 0.914 & 0.024 & 0.934 & 0.025 \\
\hline$\omega$ & 0.047 & 0.110 & 0.310 & 0.093 \\
\hline$\beta$ & 0.913 & 0.062 & 0.879 & 0.078 \\
\hline Implied $\lambda$ & 0.014 & & 0.007 & \\
\hline
\end{tabular}

\begin{tabular}{lccll}
\hline \multicolumn{5}{c}{ Imposing $\beta=1$} \\
\hline$\theta$ & 0.906 & 0.037 & 0.970 & 0.101 \\
Implied $\lambda$ & 0.020 & 0.117 & 0.336 & 0.096 \\
\hline$\theta$ & 0.009 & & 0.0005 & \\
\hline & \multicolumn{4}{c}{ 1960:Q1-2007:Q2 } \\
$\beta$ & 0.872 & 0.034 & 0.889 & 0.040 \\
Implied $\lambda$ & 0.180 & 0.137 & 0.387 & 0.153 \\
\hline$\theta$ & 1.000 & 0.036 & 0.984 & 0.040 \\
$\omega$ & 0.013 & & 0.007 & \\
Implied $\lambda$ & 0.872 & Imposing $\beta=1$ & 0.042 \\
\hline
\end{tabular}

Notes: $\quad$ (a) Moment condition $1=E\left(\left(\phi \pi_{t}-\theta \beta \pi_{t+1}-\omega \pi_{t-1}-(1-\omega)(1-\theta)(1-\beta \theta) m c_{t}\right) z_{t}\right)=0$.

(b) Moment condition $2=E\left(\left(\pi_{t}-\frac{\theta \beta}{\phi} \pi_{t+1}-\frac{\omega}{\phi} \pi_{t-1}-\frac{(1-\omega)(1-\theta)(1-\beta \theta)}{\phi} m c_{t}\right) z_{t}\right)=0$.

$z_{t}$ is an element of the time $t$ information set; $\phi \equiv \theta+\omega[1-\theta(1-\beta)]$. Estimated using non-linear 2SLS with Newey-West standard errors (using 12 lags). Instruments: constant, $\pi_{t-1}$ to $\pi_{t-4}$, lags $1-2$ of the output gap, real marginal costs and nominal wages (following Galí et al 2001). 


\section{Figure 5: Inflation, Marginal Costs and the Output Gap}

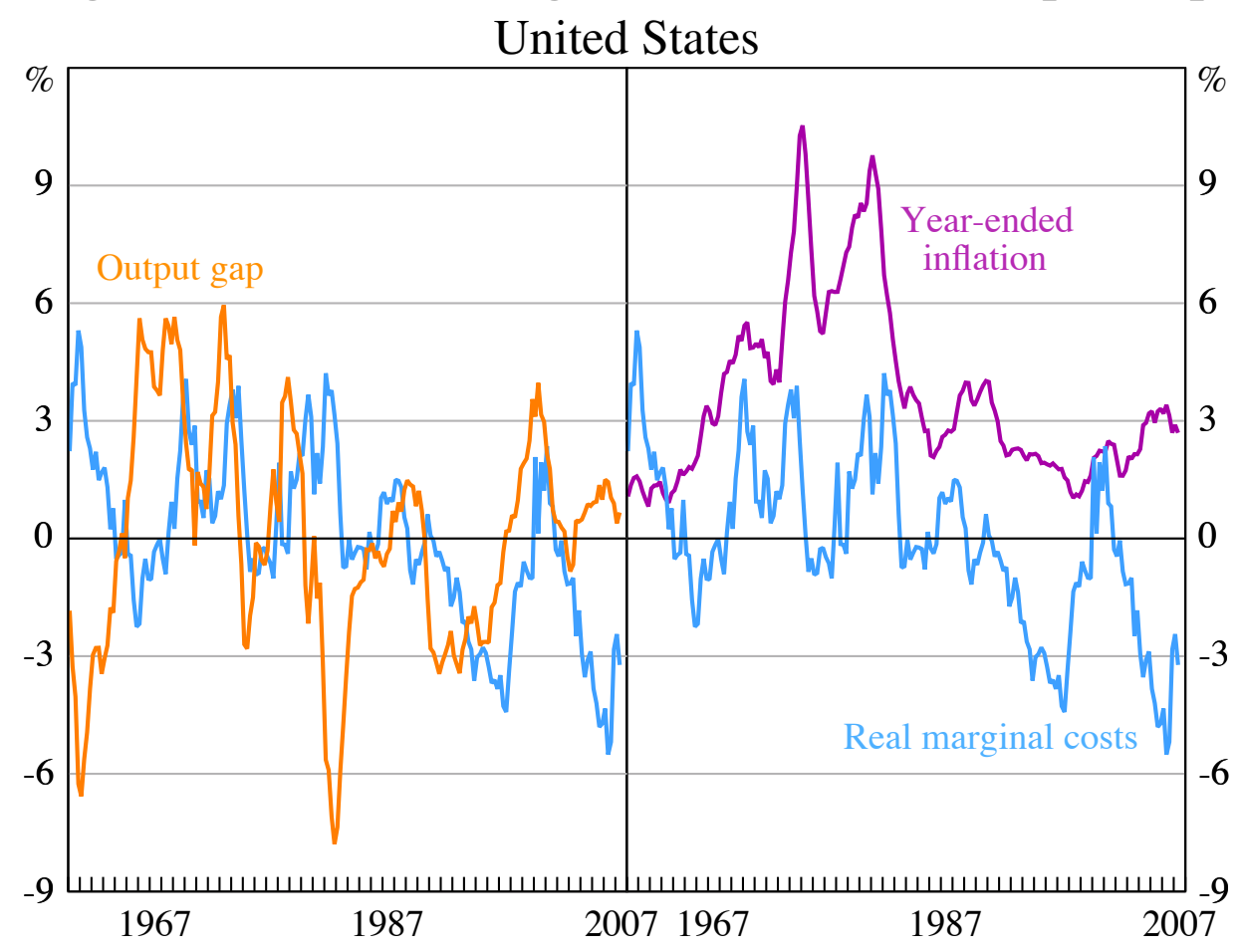

Note: The output gap is estimated using a quadratic trend, following Galí and Gertler (1999).

In contrast, an output-gap-based Phillips curve is unlikely to have forecast such subdued inflation, as the gap is estimated to have been broadly around zero over this period (Figure 5). Movements in real marginal costs appear to lag those in the output gap (by approximately one year) and the correlation between them may have decreased over time. ${ }^{21}$ However, this could be an artefact of estimating the output gap by de-trending output; in a new-Keynesian model, potential output is typically defined as the level of output that would prevail under flexible prices, and this may not be approximated well by de-trended output, a point emphasised by Neiss and Nelson (2005). ${ }^{22}$

21 The relationship was also weak during the 1960s (Figure 5). The correlation coefficient between real marginal costs and the output gap for the period 1970:Q1-1983:Q4 is 0.41; it declines to be 0.25 over 1984:Q1-2007:Q2.

22 In the simplest case, when the representative firm uses labour as the only factor of production, the flexible-price output gap will move proportionally to the marginal cost (see Gali 2008, chapter 3). However, when a more general production function is used, such a simple relationship between the flexible-price output gap and marginal costs may not exist. 


\section{Figure 6: Forecasts Conditional on Observed Marginal Costs}

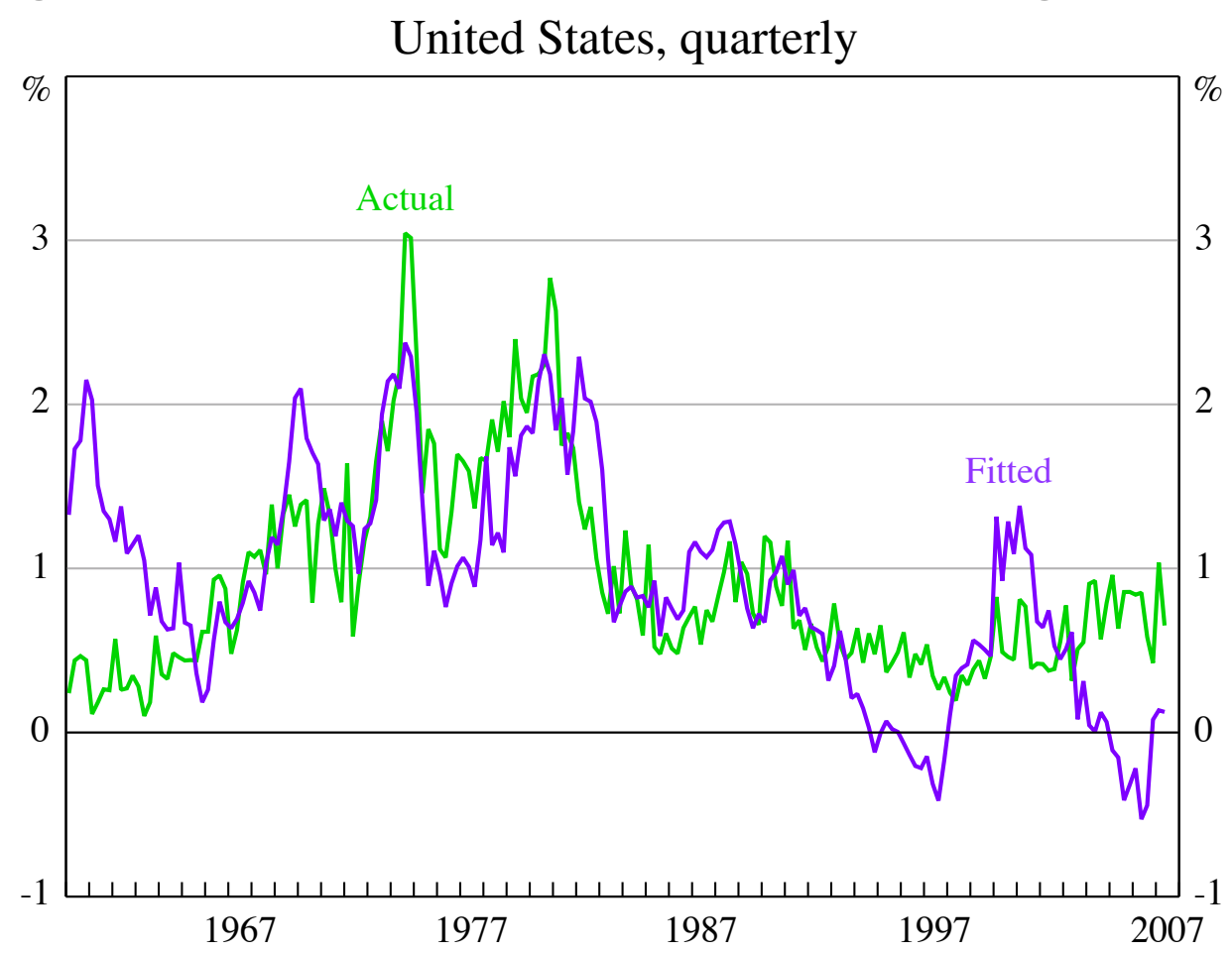

\section{Explaining the Flattening Phenomenon}

The evidence presented in Sections 2 and 4 indicates that something has changed in the way inflation responds to real marginal costs, as measured by labour's share of income. Also evident is that the relationship between the output gap (when measured as de-trended output) and labour's share of income, is far from tight. We now review the suspects which have been raised in the literature to see which (if any) can plausibly explain these observations.

The candidate explanations fall into four groups. The first is simply that there are problems with the data; that is, that the reported labour share is mismeasured in some important way. The second possibility is that the labour share is measured reasonably well - but that it is a flawed proxy for the 'true' marginal costs faced by firms. A third alternative explanation is that there may have, in fact, been structural changes to price-setting behaviour, and the reduction in the estimated sensitivity of inflation to costs is an accurate reflection of those changes. The fourth possibility is that the price-setting behaviour of firms has been time-invariant, but some other aspect of the model is invalid. The third and fourth possibilities suggest that the standard new-Keynesian framework that we have used here is too simple, and needs to be modified so as to better capture the inflation process. 


\subsection{Data Problems}

At first glance, an appealing feature of the new-Keynesian framework is that it does not depend on the output gap, which is unobserved and therefore difficult to estimate, particularly in real time (see, for example, Orphanides and van Norden 2002). However, measuring marginal cost is not straightforward either. As noted above, the conventional measure of real marginal cost is labour's share of nominal output:

$$
\frac{W \times N}{P \times Y},
$$

where: $W$ is average compensation per-hour; $N$ is total hours; $Y$ is real output; and $P$ is the price level. This is equivalent to unit labour costs $-(W \times N) / Y$, that is, productivity-adjusted wages - deflated by the price level. In order to avoid problems associated with measuring agricultural and government output, the standard practice for the United States has been to use the labour share of income for the non-farm business sector. However, even when we constrain our attention to the non-farm business sector, considerable measurement problems may still exist, many of which are outlined in Krueger (1999). Examples of such issues include what constitutes income (for example, whether to include stock options, fringe benefits, etc), whether distinctions based on a firm being incorporated or not are useful, and whether proprietors' income should be included in returns to capital or labour. Some of these issues have the potential to not only alter the level of labour's share of income, but also to contribute to long-term trends. An example of this is the shift of proprietors to salaried employees that occurred in the United States in the first half of the $20^{\text {th }}$ century (see Krueger 1999, and the references therein).

It is impossible to know for sure the extent of these data problems; however, they would have to be quite large to account for the shift in labour's share of income that has occurred in the United States. ${ }^{23}$

23 Using the labour share for only the non-financial corporate sector (where Corrado and Slifman (1999) argue the data problems are less severe) also suggests that a flattening in the Phillips curve has occurred. 


\subsection{Labour Share $\neq$ Marginal Cost}

Another logical possibility is that the labour share data are basically sound, but that the labour share is a poor proxy for firms' true marginal cost. It has long been known that the conditions under which labour's share is proportional to marginal cost are highly restrictive: sufficient conditions are that the production function is Cobb-Douglas (or more precisely, isoelastic with respect to labour), and free from complications such as labour hoarding, overhead labour, etc. ${ }^{24}$ Rotemberg and Woodford (1999) provide a comprehensive survey of how such complications would affect the cyclicality of labour's share. What Rotemberg and Woodford do not consider, however, is the possibility of prolonged, and possibly structural, changes in labour's share of income, like that which seems to have taken place in the United States. ${ }^{25}$

\subsubsection{Open economy dimensions}

An obvious reason why labour's share may not capture marginal costs well is that it omits open-economy aspects, which are likely to be of importance, particularly for small, open economies. To examine whether there is still evidence of a structural flattening once these factors are accounted for, we estimate new-Keynesian Phillips curves for Australia.

In introducing the open-economy aspects, it is useful to distinguish between two stages of pass-through of exchange rates to consumer prices: the first being from world prices to import prices 'at the docks', and the second from these prices at the docks to consumer prices. Past evidence for Australia (for example, Dwyer and Leong 2001) suggests that first-stage pass-through is rapid, whereas the second stage is prolonged. Incomplete short-run pass-through has also been found for other economies - see Campa and Goldberg (2002). A simple way to introduce this in a new-Keynesian framework was developed by Monacelli (2006). In brief, he assumes that the CPI can be split into prices of domestically produced goods and prices of foreign goods. Prices of domestically produced goods evolve as sketched

24 Overhead labour is labour hired independently of the quantity of output produced.

25 They do, however, note that there appears to have been a sizeable increase in labour's share in the non-financial corporate sector during the late 1960s. 
in Section 3.1. The law of one price is assumed to hold at the docks, that is, firststage pass-through is complete. Incomplete short-run second-stage pass-through is captured by introducing Calvo pricing. Essentially, we obtain two Phillips curves, one each for domestically produced and foreign goods. In the latter, the measure of marginal costs are import prices at the docks relative to the retail price of foreign goods, which Monacelli (2006) terms the 'law-of-one-price-gap'.

Such a system of Phillips curves have been estimated for Australia as part of a small DSGE model by both Nimark (2007) and Justiniano and Preston (forthcoming). In these models the retail price of foreign-produced goods is treated as an unobserved variable, and is estimated using the Kalman filter. Unfortunately, a direct measure of these prices is not available and, therefore, in order to estimate a Phillips curve using the same methods as above, we make the simplifying assumption that the Calvo parameter is the same in the domestically produced and foreign goods. This assumption is not supported by Nimark (2007) and Justiniano and Preston (forthcoming), who find that it differs across the sectors although, interestingly, Justiniano and Preston find the duration between price changes to be less for foreign goods, whereas Nimark finds the opposite. ${ }^{26}$ The resulting aggregate Phillips curve which incorporates import prices is of the form:

$$
\pi_{t}=\gamma_{f} E_{t} \pi_{t+1}+\gamma_{b} \pi_{t-1}+\lambda\left((1-\alpha) m c_{t}^{d}+\alpha m c_{t}^{m}\right),
$$

where: $\alpha$ is the share of foreign goods in consumption; and $d$ and $m$ denote domestically produced goods and imports, respectively. Essentially, real marginal costs are a weighted average of marginal costs in each sector, with the weights determined by their importance in the consumption bundle. ${ }^{27}$ Substituting in our expressions for marginal costs (and letting lower-case letters denote natural logs of variables) yields the equation we estimate:

$$
\pi_{t}=\gamma_{f} E_{t} \pi_{t+1}+\gamma_{b} \pi_{t-1}+\lambda\left((1-\alpha)\left(w_{t}+n_{t}-y_{t}-p_{t}\right)+\alpha\left(p_{t}^{m}-p_{t}\right)\right) .
$$

26 We also assume that the share of firms that use rule-of-thumb pricing, $\omega$, is common across the sectors, which was imposed by Nimark (2007).

27 This specification ignores imports of intermediate materials. If materials enter the gross output production function 'isoelastically', then the materials share is another potential measure of marginal costs (see Rotemberg and Woodford 1999). Batini, Jackson and Nickell (2005) argue that introducing intermediate materials is important for capturing the behaviour of UK inflation. Their model does not use the Calvo framework described above, but is motivated by the quadratic adjustment costs described in Rotemberg (1982). 
This specification of marginal costs is strikingly similar to the long-run term in mark-up error-correction mechanism equations which have traditionally been used to model Australian inflation (for example, de Brouwer and Ericsson 1998). Interestingly, when modeling the CPI, the labour share will be an imperfect measure of real marginal costs, independent of any open economy aspects, as it deflates nominal marginal costs (unit labour costs) by the GDP deflator rather than the CPI ${ }^{28}$ As the weight of imported goods in consumption, $\alpha$, has been a difficult parameter to estimate in the past (see Kulish and Rees 2008), we also try a variant in which it is calibrated to $0.2{ }^{29}$ The results presented in Table 3 suggest that even when open economy aspects are added to the Phillips curve a flattening is evident.

\begin{tabular}{|c|c|c|c|c|c|c|}
\hline \multicolumn{7}{|c|}{$\begin{array}{l}\text { Table 3: Open Economy New-Keynesian Phillips Curve - Australia } \\
\qquad \pi_{t}=\gamma_{f} E_{t} \pi_{t+1}+\gamma_{b} \pi_{t-1}+\lambda\left((1-\alpha)\left(w_{t}+n_{t}-y_{t}-p_{t}\right)+\alpha\left(p_{t}^{m}-p_{t}\right)\right)\end{array}$} \\
\hline Coefficient & \multicolumn{2}{|c|}{ 1960:Q1-1992:Q4 } & \multicolumn{2}{|c|}{ 1993:Q1-2007:Q2 } & \multicolumn{2}{|c|}{ 1960:Q1-2007:Q2 } \\
\hline & Value & $\begin{array}{l}\text { Standard } \\
\text { error }\end{array}$ & Value & $\begin{array}{c}\text { Standard } \\
\text { error }\end{array}$ & Value & $\begin{array}{l}\text { Standard } \\
\text { error }\end{array}$ \\
\hline$\overline{\gamma_{b}}$ & 0.180 & 0.104 & 0.382 & 0.045 & 0.165 & 0.096 \\
\hline$\gamma_{f}$ & 0.777 & 0.117 & 0.596 & 0.048 & 0.804 & 0.112 \\
\hline$\lambda$ & 0.004 & 0.003 & 0.002 & 0.004 & 0.004 & 0.003 \\
\hline \multirow[t]{2}{*}{$\alpha$} & 0.354 & 0.404 & 0.226 & 0.439 & 0.327 & 0.282 \\
\hline & \multicolumn{6}{|c|}{ Imposing $\alpha=0.2$} \\
\hline$\overline{\gamma_{b}}$ & 0.181 & 0.104 & 0.382 & 0.045 & 0.166 & 0.096 \\
\hline$\gamma_{f}$ & 0.776 & 0.118 & 0.596 & 0.047 & 0.806 & 0.111 \\
\hline \multirow[t]{2}{*}{$\lambda$} & 0.004 & 0.003 & 0.002 & 0.002 & 0.003 & 0.003 \\
\hline & \multicolumn{6}{|c|}{ Imposing $\alpha=0.2$ and $\gamma_{f}+\gamma_{b}=1$} \\
\hline$\overline{\gamma_{b}}$ & 0.175 & 0.099 & 0.387 & 0.049 & 0.161 & 0.092 \\
\hline$\lambda$ & 0.002 & 0.002 & 0.001 & 0.001 & 0.002 & 0.002 \\
\hline Notes: & ed usin $1-2$ & $\begin{array}{l}\text { with New } \\
\text { tput gap, } 1\end{array}$ & $\begin{array}{l}\text { standar } \\
\text { abour c }\end{array}$ & $\begin{array}{l}\text { s (using } 1 \\
\text { al import }\end{array}$ & $\begin{array}{l}\text { Instrume } \\
\text { d nomina }\end{array}$ & $\begin{array}{l}\text { nstant, } \pi_{t-1} \text { to } \\
\text { s. }\end{array}$ \\
\hline
\end{tabular}

28 We use the trimmed-mean CPI adjusted for the introduction of the GST. Nominal unit labour costs are for the non-farm sector. Import prices are measured as the implicit price deflator from the balance of payments, adjusted for changes in average tariff rates, following Beechey et al (2000), using data from Stone, Wheatley and Wilkinson (2005) and Gruen, Robinson and Stone (2005).

29 This is approximately the share of imports in GDP over the inflation-targeting period. 


\subsubsection{Changing sectoral composition}

The observed evolution of labour's share for the United States may also reflect changes in the sectoral composition of output. McAdam and Willman (2004) show, using a disaggregated supply-side model, that shifts across sectors will affect the aggregate equilibrium mark-up, and thus labour's share. Their model includes two sources of such shifts: one is differential technical progress across sectors, which induces changes in relative prices and hence demand; the second is changes in the (exogenous) price of exports, relative to foreign goods.

Based on their model, they propose a correction to the measured labour share, which essentially is an adjustment for a time trend (capturing differentials in productivity growth) and the relative export price. They claim that this adjustment makes euro-area marginal cost stationary, and greatly improves the performance of the new-Keynesian Phillips curve. However, the results from Lawless and Whelan (2007), which estimate disaggregated inflation equations based on sectoral-level mark-ups, are less supportive of an important role for sectoral shifts in explaining the behaviour of labour's share.

\subsection{Structural Changes in Price-setting Behaviour}

In explaining the apparent flattening of the new-Keynesian Phillips curve, a logical possibility is that there really has been a change in underlying price-setting behaviour. A number of hypotheses fall under this rubric, and many of these are based on the idea that globalisation has fundamentally changed the economy's behaviour.

\subsubsection{The Rogoff hypothesis}

Perhaps the best-known of these is that of Rogoff (2003) and Rogoff (2006). His hypothesis incorporates two distinct effects: first, that globalisation has increased pricing 'flexibility' (that is, reduced $\theta$, the share of firms not adjusting in any given period); and second, that increased competition has reduced product markups. Rogoff argues that both of these effects will tend to increase the slope of the Phillips curve. Policy-makers, now faced with a less-favourable short-term outputinflation trade-off, will be less tempted to pursue expansionary policies in order to boost output - and this will, in turn, reduce the Barro-Gordon inflation bias. 
However, as pointed out by Ball (2006), the problem with the Rogoff hypothesis is that its implication with regard to the slope of the Phillips curve is precisely the opposite of what one sees in the data: the Phillips curve has become flatter, not steeper. Moreover, the smaller equilibrium mark-up implied by the increase in competition would imply a larger labour share, and thus is inconsistent with the observed downward movement for the United States. Consequently, it seems safe to join Ball in dismissing the Rogoff hypothesis.

\subsubsection{Increased openness of product and labour markets}

Another globalisation-related hypothesis is that greater openness means that increases in domestic demand are increasingly satisfied through imports, rather than domestic production. This implies that increases in the output gap will have smaller effects on domestic marginal costs - and hence, muted inflationary consequences. This mechanism has been incorporated in the model developed in Razin and Binyamini (2007) and is consistent with the view expressed in Borio and Filardo (2007). A corollary is that the global output gap has become more important as a determinant of inflation. Similarly, Borio and Filardo argue that increased openness of labour markets should attenuate the inflationary effects of output fluctuations. For an overview of the channels through which globalisation may impact on the inflation process, see Bernanke (2007).

Increased openness, however, is probably insufficient to explain the flattening of the new-Keynesian Phillips curve. The reason is simple: while both developments would tend to weaken the link between the output gap and marginal costs, neither of the mechanisms above are likely to affect the link from expected future costs to inflation. In the estimates above for Australia, the share of imported goods in the consumption bundle appears to have fallen, although this is imprecisely estimated and is at odds with the increase in the share of imports in GDP evident in the data. In recent years, the greater role of China in the world economy has undoubtedly held down the price of imported manufactured goods, and increased competition may have encouraged domestic firms to be more productive. Such effects, however, would only change the behaviour of marginal costs, and 
estimates of the new-Keynesian specification, which rely on measures of marginal cost rather than the output gap, should be immune to these issues. ${ }^{30,31}$

\subsection{The Need for a Richer Structural Model}

A final possible explanation for apparent flattening in the typical new-Keynesian Phillips curve is that the pricing behaviour of firms has not changed, but that the structural model we have estimated is itself too simple. An example is Ascari (2004), who argues that relaxing the simplifying assumption of no-trend inflation considerably alters the Calvo model. Alternatively, our results suggest that the frequency of price setting may be dependent on the average inflation rate, as price resetting is estimated to have been more frequent in the 1970s than subsequently, an idea also raised by Ball, Mankiw and Romer (1988). This raises a possible indirect way that monetary policy may have influenced the slope of the Phillips curve, namely by achieving lower-trend inflation, it has created an environment in which firms reset their prices less frequently. ${ }^{32}$ While we have interpreted the Calvo parameter as a 'deep' parameter, really the Calvo framework imposes a constraint on optimal behaviour in order to produce nominal rigidities rather than providing a truly behavioural reason why they occur. Consequently, it is not implausible that the frequency with which prices are reset may be time-varying. To fully investigate this we obviously need a considerably richer structural model. Cogley and Sbordone (2005) estimate a new-Keynesian Phillips curve with trend inflation and allow the parameters to vary over time. They, too,

30 Sbordone (2007) examines the implications of globalisation in a variant of the new-Keynesian Phillips curve. In particular, she builds on Kimball (1995) to allow the possibility that the increased variety of goods available as a consequence of globalisation alters the market share of each good and hence their price elasticity of demand and the slope of the new-Keynesian Phillips curve. However, Sbordone argues that the observed increase in trade is probably insufficient to have caused a decrease in the slope.

31 Globalisation may lead to changes in the mark-up, for example, due to sectoral change. This would have a permanent impact on the price level although, as Mishkin (2007a) notes, the effect on inflation should be temporary.

32 As Sbordone (2007) notes, one could argue that, if globalisation has assisted in creating this low inflation environment through restraining growth in marginal costs, then it has also indirectly contributed to the flattening of the Phillips curve. 
find that the duration of between-price resetting was shortest in the 1970s and longest in the Greenspan era. ${ }^{33}$

\section{Conclusions}

It is now 50 years after Phillips first observed the relationship between unemployment and wages, variants of which now occupy a critical position in the intellectual framework underpinning monetary policy. Recently, policy-makers have observed that fluctuations in activity do not appear to be as inflationary as in the past, which is borne out by our estimates of reduced-form Phillips curves. This paper has attempted to summarise some of the common arguments cited regarding why this has occurred, using the standard new-Keynesian Phillips curve as an organising framework. Our estimates suggest that there has also been a flattening in this 'structural' model, that is, there has been a change in the pricesetting behaviour of firms. In particular, it appears that the duration between price resetting may have lengthened. Many of the common explanations for changes in the price-setting behaviour of firms are related to globalisation. While globalisation may alter the relationship between the output gap and marginal costs, it is unclear why it would alter the link between marginal costs and inflation in a way that corresponds to a flattening of the Phillips curve. In a structural model, the deep parameters in the Phillips curve should be invariant to changes in the conduct of monetary policy. However, one potential explanation is that lower-trend inflation resulting from the improved conduct of monetary policy may account for the more infrequent price resetting and hence the flattening Phillips curve, a possibility which is not accommodated in the benchmark new-Keynesian model. In all, it appears that after 50 years there is still considerable work to be done in order to fully understand the relationship between aggregate activity and inflation.

33 Groen and Mumtaz (2008) alternatively argue that the Calvo parameter has not increased. 


\section{References}

Adolfson M, S Laséen, J Lindé and M Villani (2007), 'Bayesian Estimation of an Open Economy DSGE Model with Incomplete Pass-Through', Journal of International Economics, 72(2), pp 481-511.

Ascari G (2004), 'Staggered Prices and Trend Inflation: Some Nuisances', Review of Economic Dynamics, 7(3), pp 642-667.

Ball LM (2006), 'Has Globalization Changed Inflation?', NBER Working Paper No 12687.

Ball LM, NG Mankiw and D Romer (1988), 'The New Keynesian Economics and the Output-Inflation Trade-off', Brookings Papers on Economic Activity, 1, pp 1-65.

Batini N, B Jackson and $\mathbf{S}$ Nickell (2005), 'An Open-Economy New Keynesian Phillips Curve for the U.K.', Journal of Monetary Economics, 52(6), pp 1061-1071.

Bean C (2006), 'Globalisation and Inflation', Bank of England Quarterly Bulletin, 46(4), pp 468-475.

Beaudry P and M Doyle (2000), 'What Happened to the Phillips Curve in the 1990s in Canada?', in Price Stability and the Long-Run Target for Monetary Policy, Proceedings of a Conference, Bank of Canada, Ottawa, pp 51-82.

Beechey M, N Bharucha, A Cagliarini, D Gruen and C Thompson (2000), 'A Small Model of the Australian Macroeconomy', RBA Research Discussion Paper No 2000-05.

Bernanke BS (2007), 'Globalization and Monetary Policy', speech given at the Fourth Economic Summit, Stanford Institute for Economic Policy Research, Stanford, 2 March.

Bils $M$ and PJ Klenow (2004), 'Some Evidence on the Importance of Sticky Prices’, Journal of Political Economy, 112(5), pp 947-985. 
Binder $M$ and MH Pesaran (1995), 'Multivariate Rational Expectations Models and Macroeconomic Modelling: A Review and Some New Results', in MH Pesaran and MR Wickens (eds), Handbook of Applied Econometrics, Volume 1: Macroeconomics, Basil Blackwell, Oxford, pp 139-187.

Borio C and A Filardo (2007), 'Globalisation and Inflation: New CrossCountry Evidence on the Global Determinants of Domestic Inflation', Bank for International Settlements Working Paper No 227.

Calvo GA (1983), 'Staggered Contracts in a Utility-Maximizing Framework', Journal of Monetary Economics, 12(3), pp 383-398.

Campa JM and LS Goldberg (2002), 'Exchange Rate Pass-Through into Import Prices: A Macro or Micro Phenomenon?', Federal Reserve Bank of New York Staff Report No 149.

Carlstrom CT, TS Fuerst and M Paustian (2007), 'Inflation Persistence, Inflation Targeting and the Great Moderation', Federal Reserve Bank of Cleveland Working Paper No 07-21.

Christiano LJ, M Eichenbaum and CL Evans (2005), 'Nominal Rigidities and the Dynamic Effects of a Shock to Monetary Policy', Journal of Political Economy, 113(1), pp 1-45.

Clarida R, J Galí and M Gertler (2000), 'Monetary Policy Rules and Macroeconomic Stability: Evidence and Some Theory', Quarterly Journal of Economics, 115(1), pp 147-180.

Cogley T and AM Sbordone (2005), 'The Search for a Structural Phillips Curve', Federal Reserve Bank of New York Staff Report No 203.

Corrado C and L Slifman (1999), 'Decomposition of Productivity and Unit Costs', American Economic Review, 89(2), pp 328-332.

de Brouwer G and NR Ericsson (1998), 'Modeling Inflation in Australia', Journal of Business and Economic Statistics, 16(4), pp 433-449.

Dwyer J and K Leong (2001), 'Changes in the Determinants of Inflation in Australia', RBA Research Discussion Paper No 2001-02. 
Galí J (2008), Monetary Policy, Inflation and the Business Cycle: An Introduction to the New Keynesian Framework, Princeton University Press, Princeton.

Galí J and M Gertler (1999), 'Inflation Dynamics: A Structural Econometric Analysis', Journal of Monetary Economics, 44(2), pp 195-222.

Galí J, M Gertler and JD Lopez-Salido (2001), 'European Inflation Dynamics', European Economic Review, 45(7), pp 1237-1270.

Galí J, M Gertler and JD Lopez-Salido (2005), 'Robustness of the Estimates of the Hybrid New Keynesian Phillips Curve', Journal of Monetary Economics, 52(6), pp 1107-1118.

Groen JJ and H Mumtaz (2008), 'Investigating the Structural Stability of the Phillips Curve Relationship', Bank of England Working Paper No 250.

Gruen DWR, T Robinson and A Stone (2005), 'Output Gaps in Real Time: How Reliable Are They?', Economic Record, 81(252), pp 6-18.

Guay A and F Pelgrin (2004), 'The U.S. New Keynesian Phillips Curve: An Empirical Assessment', Bank of Canada Working Paper No 2004-35.

Justiniano A and B Preston (forthcoming), 'Monetary Policy and Uncertainty in an Empirical Small Open Economy Model', Journal of Applied Econometrics.

Kent C and D Norman (eds) (2005), The Changing Nature of the Business Cycle, Proceedings of a Conference, Reserve Bank of Australia, Sydney.

Kimball MS (1995), 'The Quantitative Analytics of the Basic Neomonetarist Model', Journal of Money, Credit and Banking, 27(4), pp 1241-1277.

Koenig EF (2003), 'Is the Markup a Useful Real-time Predictor of Inflation?', Economics Letters, 80(2), pp 261-267.

Krueger AB (1999), 'Measuring Labor's Share', American Economic Review, 89(2), pp 45-51.

Kulish M and D Rees (2008), 'Monetary Transmission and the Yield Curve in a Small Open Economy', RBA Research Discussion Paper No 2008-03. 
Lawless $M$ and K Whelan (2007), 'Understanding the Dynamics of Labour Shares and Inflation', Central Bank and Financial Services Authority of Ireland Research Technical Paper No 4/RT/07.

Lucas, RE Jr (1976), 'Econometric Policy Evaluation: A Critique', CarnegieRochester Conference Series on Public Policy, 1(1), pp 19-46.

McAdam P and A Willman (2004), 'Supply, Factor Shares and Inflation Persistence: Re-Examining Euro-Area New-Keynesian Phillips Curves', Oxford Bulletin of Economics and Statistics, 66(S1(09)), pp 637-670.

Mishkin FS (2007a), 'Globalization, Macroeconomic Performance, and Monetary Policy', speech at the Domestic Prices in an Integrated World Economy Conference, Board of Governors of the Federal Reserve System, Washington DC, 27 September.

Mishkin FS (2007b), 'Inflation Dynamics', NBER Working Paper No 13147.

Monacelli T (2006), 'Monetary Policy in a Low Pass-Through Environment', Journal of Money, Credit and Banking, 37(6), pp 1047-1066.

Murchison S and A Rennison (2007), 'ToTEM: The Bank of Canada's New Quarterly Projection Model', Bank of Canada Technical Report No 97.

Neiss KS and E Nelson (2005), 'Inflation Dynamics, Marginal Cost, and the Output Gap: Evidence from Three Countries', Journal of Money, Credit and Banking, 37(6), pp 1019-1045.

Nimark K (2007), ‘A Structural Model of Australia as a Small Open Economy', RBA Research Discussion Paper No 2007-01.

Nimark K (2008), 'Dynamic Pricing and Imperfect Common Knowledge', Journal of Monetary Economics, 55(2), pp 365-382.

Òlafsson TT (2006), 'The New Keynesian Phillips Curve: In Search of Improvements and Adaptation to the Open Economy', Central Bank of Iceland Working Paper No 31.

Orphanides A (2002), 'Monetary-Policy Rules and the Great Inflation', American Economic Review, Papers and Proceedings, 92(2), pp 115-120. 
Orphanides A and S van Norden (2002), 'The Unreliability of OutputGap Estimates in Real Time', The Review of Economics and Statistics, 84(4), pp 569-583.

Pagan AR (2008), Lecture notes for a course given for the Economics Society (NSW).

Razin A and A Binyamini (2007), 'Flattened Inflation-Output Tradeoff and Enhanced Anti-Inflation Policy: Outcome of Globalization?', NBER Working Paper No 13280.

Roberts JM (2006), 'Monetary Policy and Inflation Dynamics', International Journal of Central Banking, 2(3), pp 193-230.

Rogoff K (2003), 'Globalization and Global Disinflation', in Monetary Policy and Uncertainty: Adapting to a Changing Economy, a Symposium sponsored by the Federal Reserve Bank of Kansas City, Jackson Hole, pp 77-112.

Rogoff K (2006), 'Impact of Globalization on Monetary Policy', in The New Economic Geography: Effects and Implications, a Symposium sponsored by the Federal Reserve Bank of Kansas City, Jackson Hole, pp 265-305.

Rotemberg JJ (1982), 'Sticky Prices in the United States', Journal of Political Economy, 90(6), pp 1187-1211.

Rotemberg JJ and M Woodford (1999), 'The Cyclical Behavior of Prices and Costs', in JB Taylor and M Woodford (eds), Handbook of Macroeconomics, Volume 1B, Elsevier Science, Amsterdam, pp 1051-1135.

Rudd J and K Whelan (2005), 'Modelling Inflation Dynamics: A Critical Review of Recent Research', Board of Governors of the Federal Reserve System FEDS Working Paper No 2005-66.

Rudebusch GD (2005), 'Assessing the Lucas Critique in Monetary Policy Models', Journal of Money, Credit and Banking, 37(2), pp 245-272.

Sargent TJ (1971), 'A Note on the "Accelerationist" Controversy', Journal of Money, Credit and Banking, 3(3), pp 721-725. 
Sbordone AM (2007), 'Globalization and Inflation Dynamics: The Impact of Increased Competition', NBER Working Paper No 13556.

Stone A, T Wheatley and L Wilkinson (2005), 'A Small Model of the Australian Macroeconomy: An Update', RBA Research Discussion Paper No 2005-11.

Williams JC (2006), 'Inflation Persistence in an Era of Well-Anchored Inflation Expectations', FRBSF Economic Letter No 2006-27. 